\title{
KAJIAN TEKNOLOGI BUDIDAYA JAGUNG SPESIFIK LOKASI PADA LAHAN SUBOPTIMAL DI KABUPATEN TAKALAR
}

\author{
Study of Location Specific Corn Cultivation Technology \\ on Suboptimal Land in Takalar District
}

\author{
Amir dan Wahid \\ Balai Pengkajian Teknologi Pertanian Balitbangtan Sulawesi Selatan \\ e-mail:amir_bio64@yahoo.com
}

Received: 3 Maret 2021; Accepted: 14 April 2021; Published: 25 Juni 2021

\begin{abstract}
ABSTRAK
Sulawesi Selatan memiliki lahan kering beriklim kering seluas 1.238.520 Ha sebagai potensi pengembangan jagung. Produktivitas tanaman pangan di lahan kering beriklim kering dapat ditingkatkan bila dikelola secara berkelanjutan dan memanfaatkan teknologi hasil-hasil penelitian. Pengkajian bertujuan melihat pengaruh paket teknologi budidaya jagung spesifik lokasi terhadap pertumbuhan dan produksi pipilan kering jagung. Kegiatan disusun menurut rancangan acak kelompolk (RAK), empat ulangan dan lima paket teknologi sebagai perlakuan. Kegiatan dilaksanakan dengan tidak mengolah tanah (TOT). Parameter pengamatan dilakukan terhadap komponen pertumbuhan dan komponen hasil tanaman jagung. Paket teknologi A memberikan produksi pipilan kering jagung tertinggi (10,5 t/ha) dan paket teknologi $\mathrm{E}$ (Kontrol) memberikan produksi pipilan kering lebih rendah (7,4 t/ha) dari paket teknologi lain. Paket teknologi A memberikan jumlah butir per kilogram biji paling sedikit (3.212 butir).
\end{abstract}

Kata kunci: Jagung, lahan kering, paket teknologi

\begin{abstract}
South Sulawesi has dry land with dry climate covering an area of 1,238,520 hectares as a potential development of maize. The productivity of food crops in dry land with dry climates can be increased if it is managed sustainably and utilizes research technology. The study aimed to see the effect of location-specific corn cultivation technology packages on the growth and production of dry shelled maize. The activities were arranged according to a randomized group design (RAK), four replications and five technology packages as treatments. Activities carried out by not cultivating the land (TOT). Observation parameters were carried out on the growth and yield components of maize. Technology package A provides the highest dry shelled corn production (10.5 t/ ha) and technology package E (Control) provides lower dry shelled production (7.4 t / ha) than other technology packages. Technology package A provides the least number of grains per kilogram of seeds (3,212 grains).
\end{abstract}

Keywords: Corn, dry land, technology package

\section{PENDAHULUAN}

Sulawesi selatan memiliki lahan suboptimal yang luas untuk pengembangan jagung. Lahan suboptimal dikelompokkan ke dalam lahan kering beriklim basah dan lahan kering beriklim kering. Sebaran lahan kering beriklim basah secara nasional terluas di Sumatera, Kalimantan dan Papua. Sedang lahan kering beriklim kering sebarannya terluas di
NTT, NTB, Jawa Timur, Kalimantan Timur, Gorontalo, dan Sulawesi Selatan (Mulyani dan Syarwani 2013)

Daerah ini memiliki lahan kering beriklim basah seluas 3.191.227 Ha dan lahan kering beriklim kering seluas 1.238 .520 ha (Murtilksono dan Anwar, 2014). Permasalahan yang terjadi pada lahan kering membutuhkan upaya ekstra agar dapat dijiadikan lahan budidaya 
yang produktif. Kendala yang ada pada lahan kering seperti 1) sulit penyediaan air untuk mendukung usahatani yang produktif, b) sifat kemasaman tanah yang tinggi ( $\mathrm{pH}$ rendah) sehingga perlu dinetralisir, c) kandungan bahan organik renda dan solum tanah dangkal, d) miskin kandungan hara sehinggga perlu pemupukan dosis tinggi dan e) tanah terkadang berbatu sehingga sulit diolah (Lukitan dan Goffar, 2013).

Guna menjamin produksi jagung hingga tahun 2025, dibutuhkan peluasan areal seluas 1,3 juta ha (Murtilaksono dan Anwar, 2014). Produktivitas tanaman pangan di lahan kering beriklim kering dapat ditingkatkan bila dikelola secara berkelanjutan, memanfaatkan teknologi hasil-hasil penelitian dan memanfaatkan air sesuai karakteristik tanahnya (Lukitan dan Gofar, 2013). Air merupakan faktor pembatas utama pada agroekosistem pengembangan jagung di lahan kering.

Sulawesi Selatan menempati urutan ke empat dalam hal luas lahan dan produksi jagung secara nasional setelah Jawa Timur, Jawa Tengah, dan Lampung (Syafruddin, 2015). Optimalisasi lahan suboptimal dapat ditempuh dengan dua pendekatan yaitu, (a) memanfaatan lahan suboptimal eksisting lebih produktif dan lestari secara intensifikasi dengan dukungan inovasi peningkatkan produksi melalui perluasan areal tanam dengan peningkatan IP, (b) melakukan ekstensifikasi yang potensial dengan prioritas lahan suboptimal yang terdegradasi atau terlantar (Haryono, 2013).

Penerapan teknologi budidaya jagung spesifik lokasi perlu dilakukan sesuai agroekosistem pengembangan untuk keberlanjutan peningkatan produksi jagung. Paket teknologi budidaya jagung spesifik lokasi pada lahan kering, dilakukan dengan meramu beberapa komponen teknologi seperti varietas, jarak tanam, penyiapan lahan, dosis pupuk dan waktu pemupukan. Kombinasi beberapa paket teknologi budidaya jagung akan terpilih satu sebagai paket rekomendasi teknologi budidaya jagung spesifik lokasi pada lahan suboptimal.

Kebutuhan air tanaman jagung tidak sebanyak jenis tanaman pangan lainnya seperti padi. Tanaman jagung lebih tahan kekurangan air pada fase vegetatif dan fase pematangan dibanding fase pembungaan dan fase penyerbukan. Dengan demikian perlu penerapan teknologi produksi yang sesuai dengan kondisi curah hujan wilayah pengembangan. Pemanfaatan teknologi budidaya jagung spesifik lokasi sangat menunjang peningkatan produksi jagung di lahan suboptimal. Penyiapan lahan pertanaman jagung dilakukan secara tidak olah tanah (TOT) yang dikombinasi komponen teknologi produksi, akan meningkatkan produksi pipilan kering jagung untuk menunjang swasembada jagung.

Pemanfaatan lahan kering dengan menggunakan teknologi cara tanam relay planting memberikan produksi pipilan kering jagung tanam pertama sebesar 6,8 t/ha dan jagung tanam kedua sebanyak 8,3 t/ha (Amir dan Baso Aliem, 2017). Pengkajian ini bertujuan melihat pengaruh paket teknologi budidaya jagung spesifik lokasi terhadap pertumbuhan dan produksi pipilan kering jagung di lahan suboptimal.

\section{METODE PENELITIAN}

\section{Tempat dan Waktu}

Pengkajian dilaksanakan pada lahan suboptimal secara partisipatif dari Januari Desember 2019 di Kabupaten Takalar.

\section{Alat dan Bahan}

Alat dan bahan yang digunakan: tugal, benih jagung hibrida sebanyak lima varietas (HJ21, BISI-2, NK-212, BiSI-18 dan NK-Sumo), pupuk organik dan anorganik serta bahan pendukung lainnya.

\section{Pelaksanaan}

Penelitian disusun menurut Rancangan Acak Kelompok, empat ulangan dan lima paket teknologi sebagai perlakuan. Parameter pengamatan: tinggi tanaman umur dua bulan, tinggi tanaman saat panen, tinggi letak tongkol, ILD, panjang baris, diameter tongkol, jumlah baris/tongkol, panjang tongkol, berat jerami, diameter tongkol, umur anthsis, umur silking, bobot 1000 biji, produksi pipilan kering dan jumlah butir per kilogram biji. Paket teknologi yang dikaji (Tabel 1). 
Tabel 1. Paket teknologi yang dikaji dalam pengkajian.

\begin{tabular}{|c|c|c|c|c|c|c|}
\hline \multirow{2}{*}{$\begin{array}{c}\text { Paket } \\
\text { Tek }\end{array}$} & \multirow{2}{*}{ Varietas } & \multirow{2}{*}{ Jarak Tanam } & \multirow{2}{*}{$\begin{array}{c}\text { Penyiapan } \\
\text { lahan }\end{array}$} & \multirow{2}{*}{ Dosis pupuk/ha } & \multicolumn{2}{|c|}{ Pupuk (hst) } \\
\hline & & & & & I & II \\
\hline A & HJ-21 & $\begin{array}{c}\text { Legowo, } 90 \times 40 \times 20 \mathrm{~cm}, 1 \\
\text { tanaman/lubang }\end{array}$ & TOT & $\begin{array}{l}400 \mathrm{~kg} \mathrm{NPK}(16: 16: 16)+ \\
124,2 \mathrm{~kg} \mathrm{~N}+36,6 \mathrm{~kg} \mathrm{P}\end{array}$ & 10 & 35 \\
\hline B & B & $\begin{array}{c}\text { Legowo, } 90 \times 40 \times 30 \mathrm{~cm}, 2 \\
\text { tanaman/lubang }\end{array}$ & TOT & $\begin{array}{l}350 \mathrm{~kg} \mathrm{NPK}(16: 16: 16)+ \\
115 \mathrm{~kg} \mathrm{~N}+23 \mathrm{~kg} \mathrm{P}\end{array}$ & 7 & 30 \\
\hline $\mathrm{C}$ & NK-212 & $\begin{array}{c}\text { Legowo, } 100 \times 50 \times 30 \mathrm{~cm}, 2 \\
\text { tanaman/lubang }\end{array}$ & TOT & $\begin{array}{l}300 \mathrm{~kg} \mathrm{NPK}(16: 16: 16)+ \\
92 \mathrm{~kg} \mathrm{~N}+13,8 \mathrm{~kg} \mathrm{P}\end{array}$ & 5 & 28 \\
\hline $\mathrm{D}$ & BISI-18 & $\begin{array}{c}\text { Tandur jajar, } 75 \times 40 \mathrm{~cm}, 2 \\
\text { tanaman/lubang }\end{array}$ & TOT & $\begin{array}{l}280 \mathrm{~kg} \mathrm{NPK}(16: 16: 16)+ \\
69 \mathrm{~kg} \mathrm{~N}+13,8 \mathrm{~kg} \mathrm{P}\end{array}$ & 4 & 28 \\
\hline E & $\begin{array}{l}\text { NK- } \\
\text { SUMO }\end{array}$ & $\begin{array}{c}\text { Tandur jajar, } 80 x 40 \mathrm{~cm}, 2 \\
\text { tanaman/lubang }\end{array}$ & TOT & $\begin{array}{l}200 \mathrm{~kg} \mathrm{NPK}(16: 16: 16)+ \\
207 \mathrm{~kg} \mathrm{~N}+10 \mathrm{~kg} \mathrm{P}\end{array}$ & 15 & 45 \\
\hline
\end{tabular}

\section{HASIL DAN PEMBAHASAN}

Lima paket teknologi budidaya jagung yang dikaji pada lahan kering beriklim kering menunjukkan pengaruh tidak nyata terhadap tinggi tanaman umur dua bulan (Tabel 2). Hal ini mengindikasikan bahwa kadar hara dalam tanah masih lebih tinggi dari batas kritis tanaman sehingga tanaman tidak respon dengan pemupukan (Khafidzin, 2003 Dalam Amir,
2017). Batas kritis kebutuhan $\mathrm{N}$ tanaman jagung 2,3 - 3,5\% bobot kering tanaman (Voss, 1993 Dalam Faesal, 2015). Tinggi tanaman jagung umur dua bulan sudah muncul bunga jantan (anthesis) namun bunga betina belum muncul sehingga belum berlangsung proses penyerbukan. Fase anthesis berlangsung 2-3 hari sebelum rambut pada tongkol keluar dan tinggi tanaman sudah hampir maksimum serta mulai menyebarkan serbuk sari (Ritchie, et.al, 1997).

Tabel 2. Pengaruh paket teknologi budidaya jagung spesifik lokasi terhadap tinggi tanaman dan diameter batang jagung umur dua bulan, umur anthesis dan silking 50\% di lahan suboptimal Kabupaten Takalar.

\begin{tabular}{ccccccccc}
\hline $\begin{array}{c}\text { Paket } \\
\text { Teknologi }\end{array}$ & $\begin{array}{c}\text { T. Tan umur dua bln } \\
(\mathrm{cm})\end{array}$ & \multicolumn{2}{c}{$\begin{array}{c}\text { D.meter btg umur } \\
\text { dua bln }(\mathrm{cm})\end{array}$} & $\begin{array}{c}\text { Umur anthesis } \\
50 \%(\mathrm{hr})\end{array}$ & $\begin{array}{c}\text { Umur silking } \\
50 \%(\mathrm{hr})\end{array}$ \\
\hline A & 224,75 & $\mathrm{a}$ & 21,14 & $\mathrm{~b}$ & 52,15 & $\mathrm{c}$ & 55,18 & $\mathrm{c}$ \\
B & 228,28 & $\mathrm{a}$ & 20,79 & $\mathrm{~b}$ & 53,03 & $\mathrm{~b}$ & 56,40 & $\mathrm{~b}$ \\
C & 223,15 & $\mathrm{a}$ & 18,27 & $\mathrm{~b}$ & 53,40 & $\mathrm{~b}$ & 56,50 & $\mathrm{~b}$ \\
$\mathrm{D}$ & 226,70 & $\mathrm{a}$ & 20,08 & $\mathrm{~b}$ & 52,35 & $\mathrm{c}$ & 55,65 & $\mathrm{c}$ \\
E & 222,53 & $\mathrm{a}$ & 23,99 & $\mathrm{a}$ & 55,97 & $\mathrm{a}$ & 58,83 & $\mathrm{a}$ \\
KK $(\%)$ & 2,54 & & 8,75 & & 0,66 & & 0,67 & \\
\hline
\end{tabular}

Angka dalam satu kolom pada setiap lajur yang diikuti huruf sama tidak berbeda nyata menurut uji berganda Duncan $5 \%$. Keterangan: Paket teknologi: (A). Varietas HJ-21, jarak tanam legowo $90 \times 40 \times 20 \mathrm{~cm} 1 \mathrm{tan} / \mathrm{lbg}$, lahan TOT, pupuk $400 \mathrm{~kg}$ NPK (16:16:16) + 124,2 kg N + 36,6 kg P, Pupuk I 10 HST dan Pupuk II 35 HST; (B). Varietas Bisi2, jarak tanam legowo 90 x 40 × 30cm 2 tan/lbg lahan TOT, pupuk $350 \mathrm{~kg} \mathrm{NPK}(16: 16: 16)+115 \mathrm{~kg} \mathrm{~N}+23 \mathrm{~kg}$ P, Pupuk I 7 HST dan Pupuk II 30 HST; (C). Varietas NK-212, jarak tanam legowo 100 x 50 x 30cm 2 tan/lbg, lahan TOT, pupuk $300 \mathrm{~kg}$ NPK (16:16:16) + $92 \mathrm{~kg} \mathrm{~N}+13,8 \mathrm{~kg}$ P, Pupuk I 5 HST dan Pupuk II 28 HST; (D). Varietas Bisi-18, jarak tanam tandur jajar 75 x 40cm 2 tan/lbg, lahan TOT, pupuk $280 \mathrm{~kg}$ NPK $(16: 16: 16)+69 \mathrm{~kg} \mathrm{~N}+13,8 \mathrm{~kg}$ P, Pupuk I 4 HST dan Pupuk II 28 HST; (E). Varietas NK-Sumo, jarak tanam tandur jajar 80 x 40 $\mathrm{cm} 2$ tan/lbg, lahan TOT, pupuk $200 \mathrm{~kg}$ NPK (16:16:16) + $207 \mathrm{~kg} \mathrm{~N}+10 \mathrm{~kg}$ P, Pupuk I 15 HST dan Pupuk II 45 HST.

Paket teknologi E memberikan ukuran diameter batang paling besar $(23,99 \mathrm{~cm})$ dan berbeda nyata dengan empat paket teknologi lainnya. Paket teknologi E dipupuk sebanyak 239 $\mathrm{N}$ setara dengan $520 \mathrm{~kg}$ Urea tertinggi dibanding empat pakket teknologi lainnya. Peran utama unsur $\mathrm{N}$ memacu pertumbuhan organ vegetatif tanaman termasuk batang. Batang jagung beruasruas dan jumlah ruas bervariasi 10-40 ruas dan umumnya tidak bercabang. Bagian tengah batang terdiri dari sel-sel parensim dengan seludang pembuluh yang diselubungi kulit keras yang 
termasuk lapisan epidermis (Franke. 1981). Batang jagung tegak dan mudah terlihat, sebagaimana sorgum dan tebu, namun tidak seperti padi atau gandum.

Paket teknologi E memberikan rerata umur anthesis 50\% (55,97 hari) dan umur silking $50 \%$ (58,83 hari) lebih lama dibanding paket teknologi lainnya (Tabel 2). Umur anthesis dan silking yang lambat mengindikasikan fase vegetatif perlakuan $\mathrm{E}$ lebih lama akibat penggunaan dosis $\mathrm{N}$ tinggi dibanding empat paket teknologi lainnya dengan dosis $\mathrm{N}$ lebih rendah.

Paket teknologi A dan D memberikan umur anthesis dan umur silking 50\% lebih singkat dan berbeda nyata dengan paket teknologi lainnya. Pada fase anthesis biomassa organ vegetatif sudah maksimum yaitu sekitar $50 \%$ dari total bobot kering tanaman. Penyerapan hara oleh tanaman pada fase ini sebanyak 60-70\% N, 50\% P dan 80-90\% K (Ritchie, et.al, 1997). Tanaman jagung termasuk tanaman berumah satu karena bunga jantan dan bunga betina letaknya dalam satu tanaman (Fischer, et.al, 1984).

Umur silking dihitung saat rambut mulai keluar dari tongkol dan lebih lambat muncul dibanding bunga jantan yang terletak di ujung batang tanaman. Letak bunga jantan dan bunga betina yang terpisah dalam satu tanaman, ditambah dengan sifat yang protrandy menyebabkan tanaman melakukan penyerbukan silang. Produksi tepung sari dari bunga jantan diperkirakan mencapai 25.000-50.000 butir tiap tanaman (Fischer, et.al, 1984). Serbuk sari yang jatuh pada rambut (silk) akan membuahi ovule dan ovule berkembang menjadi biji jagung (Sunarti, 2006). Varietas HJ-21 memiliki umur lebih genjah dibanding empat varietas jagung hibrida lainnya, hal tersebut ditandai munculnya anthesis dan siliking lebih cepat (Tabel 2).

Fase generatif dihitung saat rambut (silk) mulai keluar dari kelobot hingga biji masak fisiologis (Ritchie, 1989). Silking menandakan terbentuknya bunga betina secara sempurna. Selisih waktu antara terbentuknya bunga jantan dan bunga betina sesuai data hasil pengamatan di lapangan rata-rata tiga sampai empat hari. Selisih waktu yang lebih lama dari 3-4 hari antara munculnya anthesis dengan rambut (silk) ditambah kondisi kering dan tiupan angin kencang memicu percepatan proses pengeringan bunga jantan yang berpengaruh terhadap efektivitas penyerbukan dan penurunan produksi.

Paket teknologi A memberikan rerata panjang tongkol dan panjang baris lebih panjang dibanding paket teknologi lainnya, namun tidak berbeda nyata dengan paket teknologi $\mathrm{B}$ dan $\mathrm{C}$ terhadap panjang tongkol tapi berbeda nyata dengan semua paket teknologi terhadap panjng baris. Paket teknologi E memberikan rerata panjang tongkol dan panjang baris lebih pendek namun tidak berbeda nyata dengan paket teknologi $\mathrm{D}$ terhadap panjang tongkol dan dengan paket teknologi B dan D terhadap panjang baris (Tabel 3).

Tabel 3. Pengaruh paket teknologi budidaya jagung spesifik lokasi terhadap panjang tongkol. panjang baris, jumlah baris dan ILD jagung di lahan suboptimal Kabupaten Takalar.

\begin{tabular}{cccccc}
\hline $\begin{array}{c}\text { Paket } \\
\text { Teknologi }\end{array}$ & $\begin{array}{c}\text { Panjang tkl } \\
(\mathrm{cm})\end{array}$ & $\begin{array}{c}\text { Panjang baris } \\
(\mathrm{cm})\end{array}$ & $\begin{array}{c}\text { Jumlah baris } \\
(\text { baris })\end{array}$ & $\begin{array}{c}\text { Indeks Luas Daun } \\
\text { (ILD) }\end{array}$ \\
\hline A & 16,9 a & 16,8 a & 13,6 b & 3,43 a \\
B & 16,6 a & 15,1 bc & 11,3 c & 3,62 a \\
C & 16,3 ab & 15,8 b & 13,2 b & 2,87 a \\
D & 15,4 bc & 14,6 c & 15,2 a & 2,12 b \\
E & 14,8 c & 14,5 c & 12,9 b & 3,30 a \\
KK $(\%)$ & 4,02 & 3,22 & 4,06 & 15,24 & \\
\hline
\end{tabular}

Angka dalam satu kolom pada setiap lajur yang diikuti huruf sama tidak berbeda nyata menurut uji berganda Duncan $5 \%$. Keterangan: Paket teknologi: A). Varietas HJ-21, jarak tanam legowo 90 × 40 x 20cm 1 tan/lbg, lahan TOT, pupuk $400 \mathrm{~kg}$ NPK (16:16:16) + 124,2 kg N + 36,6 kg P, Pupuk I 10 HST dan Pupuk II 35 HST; B). Varietas Bisi-2, jarak tanam legowo 90 x 40 × 30cm 2 tan/lbg lahan TOT, pupuk $350 \mathrm{~kg}$ NPK $(16: 16: 16)+115 \mathrm{~kg} \mathrm{~N}+23 \mathrm{~kg}$ P, Pupuk I 7 HST dan Pupuk II 30 HST; C). Varietas NK-212, jarak tanam legowo 100 x 50 x 30cm 2 tan/lbg, lahan TOT, pupuk $300 \mathrm{~kg}$ NPK (16:16:16) + $92 \mathrm{~kg} \mathrm{~N}+13,8 \mathrm{~kg}$ P, Pupuk I 5 HST dan Pupuk II 28 HST; D). Varietas Bisi-18, jarak tanam tandur jajar 75 x 40cm 2 tan/lbg, lahan TOT, pupuk $280 \mathrm{~kg}$ NPK (16:16:16) + $69 \mathrm{~kg} \mathrm{~N}+13,8 \mathrm{~kg}$ P, Pupuk I 4 HST dan Pupuk II 28 HST; E). Varietas NK-Sumo, jarak tanam tandur jajar 80 x 40cm 2 tan/lbg, lahan TOT, pupuk 200 kg NPK (16:16:16) + 207 kg N + 10 kg P, Pupuk I 15 HST dan Pupuk II 45 HST. 
Panjang tongkol termasuk komponen produksi yang ikut menunjang kenaikan produksi apabila didukung komponen produksi lain seperti panjang baris. Panjang tongkol tanpa ditunjang panjang baris memberikan ruang tanpa biji yang panjang pada jenggel dan tidak menunjang kenaikan produksi jagung. Namun panjang tongkol dibarengi panjang baris umumnya meningkatkan produksi. Paket teknologi A dengan sejumlah komponen tekhnologi seperti varietas HJ-21 memberikan panjang tongkol yang ditunjang panjang baris sehingga memberikan produksi pipilan kering jagung yang optimal 10,5 t/ha (Tabel 5).

Paket teknologi D memberikan rerata jumlah baris paling banyak (15,2 baris) dan berbeda nyata dengan paket teknologi lainnya. Paket teknologi B memberikan rerata jumlah baris paling sedikit (11,3 baris) dan berbeda nyata dengan paket teknologi lainnya (Tabel 3).

Paket teknologi D memberikan indeks luas daun lebih kecil $(2,12)$ dan berbeda nyata dengan paket teknologi lainnya. Hal tersebut disebabkan secara genetik bentuk daun varietas
Bisi-18 berukuran sedang dan tegak (Aqil, dkk, 2012). Indeks luas daun merupakan ratsio luas daun persatuan luas tanah. Jumlah sinar surya yang menembus permukaan daun tergantung susunan daun (Salisburi and Ross, 1978). Daun berperan penting dalam penyerapan radiasi surya dan pengaruhnya terhadap pertumbuhan dan produksi. Menurut hasil penelitian apabila ILD jagung lebih besar dari tiga maka 95\% sinar surya diserap dan apabila lebih besar dari 5(lima) maka, penyerapan surya menurun karena daun saling tumpang tindih dan daun saling menutupi (Wereing and Cooper, 1971). Semakin besar nilai indeks luas daun semakin banyak daun bagian bawah kurang mendapat sinar matahari. Nilai ILD jagung yang lebih besar dari lima menyebabkan serapan surya menurun karena daun saling menutup (Tollenaar, M. 1977).

Paket teknologi E memberikan rerata diameter tongkol paling besar namun tidak berbeda nyata dengan paket teknologi A. Paket teknologi B memberikan rerata diameter tongkol paling kecil $(39,76 \mathrm{~mm})$ dan berbeda nyata dengan paket teknologi lainnya (Tabel 4).

Tabel 4. Pengaruh paket teknologi budidaya jagung spesifik lokasi terhadap diameter tongkol, diameter jenggel, diameter batang dan tinggi tanaman jagung jelang panen di lahan suboptimal Kabupaten Takalar.

\begin{tabular}{cccccc}
\hline $\begin{array}{c}\text { Paket } \\
\text { Teknologi }\end{array}$ & Diameter tkl $(\mathrm{mm})$ & $\begin{array}{c}\text { Diameter jgel } \\
(\mathrm{mm})\end{array}$ & $\begin{array}{c}\text { Diameter btg } \\
(\mathrm{mm})\end{array}$ & $\begin{array}{c}\text { T. Tan.jelang panen } \\
(\mathrm{cm})\end{array}$ \\
\hline A & $44,84 \mathrm{ab}$ & $25,87 \mathrm{a}$ & $18,55 \mathrm{~b}$ & $230,15 \mathrm{a}$ \\
B & $39,76 \mathrm{c}$ & $21,83 \mathrm{c}$ & 18,05 & $\mathrm{~b}$ & $229,35 \mathrm{a}$ \\
C & $43,22 \mathrm{~b}$ & $24,67 \mathrm{ab}$ & $16,81 \mathrm{~b}$ & $225,30 \mathrm{a}$ \\
D & $43,81 \mathrm{~b}$ & $24,17 \mathrm{~b}$ & $17,17 \mathrm{~b}$ & $230,03 \mathrm{a}$ \\
E & $46,44 \mathrm{a}$ & $25,74 \mathrm{a}$ & $21,55 \mathrm{a}$ & $224,88 \mathrm{a}$ \\
KK $(\%)$ & 3,41 & 3,61 & 7,92 & 5,83 \\
\hline
\end{tabular}

Angka dalam satu kolom pada setiap lajur yang diikuti huruf sama tidak berbeda nyata menurut uji berganda Duncan $5 \%$. Keterangan: Paket teknologi: A). Varietas HJ-21, jarak tanam legowo $90 \times 40 \times 20 \mathrm{~cm} 1 \mathrm{tan} / \mathrm{lbg}$, lahan TOT, pupuk 400 kg NPK (16:16:16) + 124,2 kg N + 36,6 kg P, Pupuk I 10 HST dan Pupuk II 35 HST; B). Varietas Bisi-2, jarak tanam legowo 90 × 40 x 30cm 2 tan/lbg lahan TOT, pupuk $350 \mathrm{~kg} \mathrm{NPK}(16: 16: 16)+115 \mathrm{~kg} \mathrm{~N}+23 \mathrm{~kg}$ P, Pupuk I 7 HST dan Pupuk II 30 HST; C). Varietas NK-212, jarak tanam legowo $100 \times 50 \times 30 \mathrm{~cm} 2 \tan / \mathrm{lbg}$, lahan TOT, pupuk $300 \mathrm{~kg}$ NPK (16:16:16) + $92 \mathrm{~kg} \mathrm{~N}+13,8 \mathrm{~kg}$ P, Pupuk I 5 HST dan Pupuk II 28 HST; D). Varietas Bisi-18, jarak tanam tandur jajar 75 x 40cm 2 tan/lbg, lahan TOT, pupuk $280 \mathrm{~kg} \mathrm{NPK}(16: 16: 16)+69 \mathrm{~kg} \mathrm{~N}+13,8 \mathrm{~kg}$ P, Pupuk I 4 HST dan Pupuk II 28 HST; E). Varietas NK-Sumo, jarak tanam tandur jajar 80 x 40cm 2 tan/lbg, lahan TOT, pupuk 200 kg NPK (16:16:16) + 207 kg N + 10 kg P, Pupuk I 15 HST dan Pupuk II 45 HST.

Tongkol merupakan komponen produksi jagung yang terdiri dari jenggel dan biji yang terbungkus kelobot. Diameter tongkol merupakan ukuran jenggel bersama biji. Untuk mengetahui diameter jenggel, maka biji yang melekat pada jenggel dipipil terlebih dahulu sebelum dilakukan pengukuran. Paket teknologi
A memberikan diameter jenggel lebih besar $(25,87 \mathrm{~mm})$ namun tidak berbeda nyata dengan paket teknologi C dan E (Tabel 4).

Paket teknologi B memberikan diameter jenggel paling kecil $(21,83 \mathrm{~mm})$ dan berbeda nyata dengan paket teknologi lainnya. Ukuran jenggel dan biji setiap varietas berbeda - berbeda. 
Jenggel dapat digunakan sebagai barometer bahwa jagung sudah fase fisiologis yang berarti jumlah bahan kering dalam biji sudah $100 \%$ dan jagung sudah siap panen.

Paket teknologi E memberikan diameter batang lebih besar $(21,55 \mathrm{~mm})$ dan berbeda nyata dengan paket teknologi lainnya. Batang jagung salah satu organ tanaman yang mendapat distribusi bahan kering dari hasil assimilat sebesar 13\% (Hanway, 1971). Pada bagian tengah batang terletak bunga betina yang muncul lebih lambat dibanding bunga jantan di ujung batang.

Lima paket teknologi yang dikaji tidak menunjukkan pengaruh nyata terhadap tinggi tanaman menjelang panen (Tabel 4). Hal ini mengindikasikan bahwa kadar hara dalam tanah masih lebih tinggi dari batas kritis tanaman sehingga tanaman tidak respon dengan pemupukan (Khafidzin, 2003). Data tinggi tanaman jagung diperlukan sebagai informasi suatu varietas dapat dikembangkan atau tidak pada wilayah endemik hama anjing dan babi.
Rerata tinggi tanaman jagung yang dikaji 220$230 \mathrm{~cm}$.

Lima paket teknologi yang dikaji secara statistik tidak menunjukkan pengaruh nyata terhadap tinggi letak tongkol. Hal ini menggambarkan posisi letak tongkol jagung secara genetik seragam pada bagian tengah batang. Posisi letak tongkol pada batang jagung terbagi tiga, ada dipertengahan batang, lebih tinggi dari tengah batang dan lebih rendah dari tengah batang.

Paket teknologi E memberikan bobot jerami terbanyak (13,7 t/ha) namun tidak berbeda nyata dengan paket teknologi A (Tabel 5). Biomassa dari jagung terdiri dari batang, kelobot dan jenggel. Jerami jagung dapat dikelola menjadi pakan ternak ruminansia besar karena mengandung serat kasar 27,8\%; lemak 1,5\%; protein 7,4\%; abu 10,8\% dan BETN 53,1\% (Anonim, 1983 Dalam Amir, 2010). Data tinggi letek tongkol, bobot jerami jagung, bobot 1000 biji, produksi biji pipilan kering dan jumlah butir per kg biji (Tabel 5).

Tabel 5. Pengaruh paket teknologi budidaya jagung spesifik lokasi terhadap tinggi letak tongkol, bobot jerami, bobot 1000 biji, produksi biji dan jumlah butir per kilogrm biji jagung di lahan suboptimal Kabupaten Takalar.

\begin{tabular}{cccccrcc}
\hline $\begin{array}{c}\text { Paket } \\
\text { Teknologi }\end{array}$ & $\begin{array}{c}\text { Tinggi letak tongkool } \\
(\mathrm{cm})\end{array}$ & $\begin{array}{c}\text { Bobot jerami } \\
(\mathrm{t} / \mathrm{ha})\end{array}$ & $\begin{array}{c}\text { Bobot 1000 biji } \\
(\mathrm{g})\end{array}$ & $\begin{array}{c}\text { Produksi biji } \\
(\mathrm{t} / \mathrm{ha})\end{array}$ & $\begin{array}{c}\text { Jumlah butir/ } \\
\mathrm{kg} \mathrm{biji}\end{array}$ \\
\hline A & 115,50 & $\mathrm{a}$ & 11,8 & $\mathrm{ab}$ & $311,25 \mathrm{a}$ & $10,5 \mathrm{a}$ & $3.212 \mathrm{~b}$ \\
$\mathrm{~B}$ & 121,35 & $\mathrm{a}$ & 10,8 & $\mathrm{~b}$ & $300,00 \mathrm{a}$ & $9,5 \mathrm{a}$ & $3.333 \mathrm{~b}$ \\
$\mathrm{C}$ & 119,70 & $\mathrm{a}$ & 10,7 & $\mathrm{~b}$ & $298,00 \mathrm{a}$ & $8,6 \mathrm{ab}$ & $3.355 \mathrm{~b}$ \\
$\mathrm{D}$ & 108,68 & $\mathrm{a}$ & 8,4 & $\mathrm{c}$ & $271,75 \mathrm{a}$ & $8,2 \mathrm{ab}$ & $3.679 \mathrm{a}$ \\
E & 107,53 & $\mathrm{a}$ & 13,7 & $\mathrm{a}$ & $270,75 \mathrm{a}$ & $7,4 \mathrm{~b}$ & $3.693 \mathrm{a}$ \\
KK $(\%)$ & 8,36 & & 13,01 & 9,89 & 19,81 & 3,25 \\
\hline
\end{tabular}

Angka dalam satu kolom pada setiap lajur yang diikuti huruf sama tidak berbeda nyata menurut uji berganda Duncan $5 \%$. Keterangan: Paket teknologi: A). Varietas HJ-21, jarak tanam legowo 90 x 40 x 20cm 1 tan/lbg, lahan TOT, pupuk $400 \mathrm{~kg}$ NPK (16:16:16) + 124,2 kg N + 36,6 kg P, Pupuk I 10 HST dan Pupuk II 35 HST; B). Varietas Bisi-2, jarak tanam legowo 90 x 40 x 30cm 2 tan/lbg lahan TOT, pupuk $350 \mathrm{~kg} \mathrm{NPK}(16: 16: 16)+115 \mathrm{~kg} \mathrm{~N}+23 \mathrm{~kg}$ P, Pupuk I 7 HST dan Pupuk II 30 HST; C). Varietas NK-212, jarak tanam legowo $100 \times 50$ x 30cm 2 tan/lbg, lahan TOT, pupuk $300 \mathrm{~kg}$ NPK (16:16:16) + $92 \mathrm{~kg} \mathrm{~N}+13,8 \mathrm{~kg}$ P, Pupuk I 5 HST dan Pupuk II 28 HST; D). Varietas Bisi-18, jarak tanam tandur jajar 75 x 40cm 2 tan/lbg, lahan TOT, pupuk $280 \mathrm{~kg}$ NPK (16:16:16) + $69 \mathrm{~kg} \mathrm{~N}+13,8 \mathrm{~kg}$ P, Pupuk I 4 HST dan Pupuk II 28 HST; E). Varietas NK-Sumo, jarak tanam tandur jajar 80 x 40cm 2 tan/lbg, lahan TOT, pupuk 200 kg NPK (16:16:16) + 207 kg N + 10 kg P, Pupuk I 15 HST dan Pupuk II 45 HST.

Paket teknologi E memberikan bobot jerami tertinggi karena menggunakan $\mathrm{N}$ dosis tinggi $(239 \mathrm{~kg} \mathrm{~N})$ yang setara dengan $520 \mathrm{~kg}$ Urea. Nitrogen berperan dalam proses metabolisme tanaman yang memicu pertumbuhan vegetatif tanaman lebih aktif namun mempengaruhi proses reproduksi tanaman. Fotosintesa menghasilkan karbohidrat dari karbondioksida dan air, tetapi prosesnya tidak dapat berlanjut ke produksi protein, asam nukleat, dan lain-lain, jika nitrogen tidak tersedia. Dengan demikian kekurangan nitrogen yang parah akan menghentikan proses pertumbuhan dan reproduksi (Thompson and Troeh,1975). Paket teknologi D memberikan bobot jerami paling rendah $(8,4 \mathrm{t} / \mathrm{ha})$ dan berbeda nyata dengan 
empat paket teknologi lainnya. Hal tersebut diduga kadar $\mathrm{N}$ yang diberikan paling rendah dibanding paket teknologi lainnya sehingga pertumbhan organ vegetatif tidak optimal (Tabel $5)$.

Lima paket teknologi yang dikaji tidak menunjukkan pengaruh nyata terhadap bobot seribu biji namun paket teknologi A memberikan bobot seribu biji lebih berat $(311,25 \mathrm{~g})$ dibanding paket teknologi lainnya, hal tersebut dibuktikan dengan jumlah butir per kilogam biji yang lebih sedikit (3.212 butir) dibanding paket teknologi lainnya yang mengindikasikan bahwa bobot bijin paket teknologi A lebih berat (Tabel 5). Paket teknologi A yang dipupuk dengan dosis dan waktu pemupukan sesuai rekomendasi memberikan bobot 1000 biji optimal dibanding paket teknologi lainnya. Paket teknologi E dengan dosis dan waktu aplikasi pupuk menurut kebiasaan petani, memberikan bobot 1000 biji lebih ringan $(270,75 \mathrm{gr})$.

Paket teknologi A memberikan produksi biji pipilan kering jagung lebih tinggi (10,5 t/ha) dibanding paket teknologi lainnya namun tidak berbeda nyata dengan paket teknologi B, C dan D (Tabel 5). Paket teknologi E memberikan produksi pipilan kering jagung paling rendah $(7,4$ t/ha) dan berbeda nyata dengan paket teknologi A dan B. Produksi pipilan kering jagung lebih tinggi pada paket teknologi A disebabkan dosis dan aplikasi pupuk sesuai anjuran rekomendasi. Aplikasi pupuk kedua paket teknologi A pada umur 35 HST sangat tepat karena, selain penyebaran dan perkembangan akar yang cepat juga pemanjangan batang serta perkembangan bakal bunga jantan dan tongkol dimulai pada umur tersebut, sehingga tanaman menyerap hara dalam jumlah banyak (Sunarti, 2006). Produksi pipilan kering merupakan akumulasi bahan kering tanaman dari hasil fotosintat yang didistribusikan keorgan-organ tanaman yang membutuhkan. Pola distribusi hara dari total bahan kering tersebut ke tongkol $60 \%$, ke daun $20 \%$, ke batang $13 \%$ dan ke pelepah $7 \%$ (Muhajir et.al, 1977). Komposisi bahan kering biji masak fisiologis lebih dari $70 \%$ berupa pati dan sebagian besar $(80-90 \%)$ pati dalam biji terdapat dalam endosperm yang merupakan $80 \%$ dari total bobot kering biji (Boyer, C.D., and Hannah, L.C., 1994, Dalam Sunarti, 2006).

Paket teknologi A memberikan jumlah butir per kilogram biji paling sedikit (3.121 biji), ini mengindikasikan bobot butir biji lebih berat dibanding paket teknologi lainnya dengan jumlah butir lebih banyak per killlogram biji (Tabel 5). Aplikasi pupuk kedua paket teknologi A dilakukan pada umur 35 HST, dimana tanaman mulai menyerap hara dalam jumlah banyak sehingga merangsang peniyebaran dan perkembangan akar dalam mengadsorbsi hara yang memacu bobot biji. Pada umur tersebut titik tumbuh tanaman sudah diatas permukaan tanah, perkembangan dan penyebaran akar serta pemanjangan batang berlangsung cepat, serta bakal bunga jantan dan perkembangan bunga betina dimulai (Ritche, et.al, 1997). Paket teknologi D dan E memberikan jumlah butir lebih banyak dalam satu kilogram biji. Ini mengindikasikan bahwa bobot butir biji lebih ringan dibanding paket teknologi $\mathrm{A}, \mathrm{B}$ dan $\mathrm{C}$. Paket teknologi D aplikasi pupuk pertama 4 HST pertumbuhan akar belum sempurna baru empat akar seminal yang muncul, dan aplikasi pupuk kedua diberikan umur 28 HST, tanaman belum sampai tahap perkembangan dan penyebaran akar yang cepat sehingga adsorbsi hara ke organ produksi tidak maksimal (Ritchie, 1997). Aplikasi pupuk pertama dan kedua paket teknologi D tidak optimal untuk mendukung pertumbuhan dan penyebaran akar yang cepat sehingga bobot butir per satu kilogram biji lebih ringan (Tabel 5). Setiap ton hasil biji jagung dibutuhkan 27,4 kg N; 4,8 kg P dan 18,4 kg K (Cook, 1985). Meskipun jumlah hara yang diberikan ketanaman secara kuantitas mencukupi untuk pertumbuhan dan hasil biji, namun akar belum siap mengadsorbsi hara secara maksimal karena pekembangannya belum optimal.

\section{Hasil Analisis Tanah Lokasi Kegiatan}

Hasil analisis tanah lokasi kajian di lahan suboptimal Kabupaten Takalar (Tabel 6). Tanah lokasi pengkajian termasuk tekstur Lempung. Tekstur tanah adalah susnan berat nisbi fraksi pasir, debu dan liat. Suatu kelas tekstur memopunyai batas susunan tertentu dari fraksi pasir, debu dan liat (Anna, dkk, 1985). Tanah berlempung adalah bertekstur agak kasar, sedang dan halus serta sebarannya luas. Tanah berlempung memiliki sifat pasir, debu liat yag baik dan sangat sesuai untuk tanah pertanian. Tanah lempung sifatnya tidak terlalu lepas atau lengket dan tidak terlalu padat serta memilki kemampuan menyimpan air dan memiliki tata udara tanah yang baik (Anna, dkk, 1985). Tanah mengandung cukup fraksi liat untuk meyimpan 
air dan hara untuk pertumbuhan tanaman yang optimum. Tanah lempung mengandung banyak bahan organik dan sangat baik untuk daerah pertanian.

Lahan suboptimal terdiri dari lahan kering beriklim kering dan lahan kering beriklim basah. Lahan kering beriklim basah memiliki curah hujan diatas $2000 \mathrm{~mm} /$ tahun dengan waktu masa tanam selama enam bulan. Sedang pada lahan kering beriklim kering memiliki curah hujan dibawah $2000 \mathrm{~mm} /$ tahun dengan masa tanam kurang dari enam bulan (Wahyunto dan Sofyati, 2011).

Tabel 6. Hasil Analisis Tanah Lokasi setelah kegiatan selesai pada lahan suboptimal di Kabupaten Takalar

\begin{tabular}{|c|c|c|}
\hline No & Uraian & Nilai \\
\hline \multirow[t]{4}{*}{1} & Tekstur & \\
\hline & - $\quad$ Pasir/Sand (\%) & 45 \\
\hline & - $\quad$ Debu/Silt (\%) & 38 \\
\hline & - $\quad$ Liat/Clay $(\%)$ & 17 \\
\hline \multirow[t]{3}{*}{2} & $\mathrm{pH}$ & \\
\hline & $-\mathrm{H}_{2} \mathrm{O}$ & 5,46 \\
\hline & - $\mathrm{KCl}$ & 4,87 \\
\hline \multirow[t]{4}{*}{3} & Bahan Organik & \\
\hline & - Carbon $(\%)$ & 3,33 \\
\hline & - $\quad$ Nitrogen (\%) & 0,15 \\
\hline & $-\mathrm{C} / \mathrm{N}$ & 22 \\
\hline \multirow[t]{3}{*}{4} & Extract $\mathrm{HCl} 25 \%$ & \\
\hline & $-\mathrm{P}_{2} \mathrm{O}_{5}(\mathrm{mg} / 100$ gram $)$ & 34 \\
\hline & - $\quad \mathrm{K}_{2} \mathrm{O}(\mathrm{mg} / 100$ gram $)$ & 67 \\
\hline \multirow[t]{7}{*}{5} & Nilai Tukar Kation & \\
\hline & Kation-kation tukar & \\
\hline & - $\quad \mathrm{Ca}(100 /$ gram $)$ & 15,60 \\
\hline & - $\quad$ Mg (100/gram) & 0,19 \\
\hline & - $\quad$ K (100/gram) & 0,07 \\
\hline & - $\quad \mathrm{Na}(100 /$ gram $)$ & 0,13 \\
\hline & Jumlah & 15,99 \\
\hline \multirow[t]{2}{*}{6} & KTK/CEC & 29,79 \\
\hline & $\mathrm{KB} / \mathrm{BS}(\%)$ & 54 \\
\hline
\end{tabular}

\section{DAFTAR PUSTAKA}

Amir, 2010. Laporan Hasil Kegiatan. Kajian Sistem Tanam Jagung dalam Konteks Integrasi Tanaman - Ternak. Balai Pengkajian Teknologi Pertanian Sulawesi Selatan.

Amir dan Baso Aliem, 2017. Laporan Hasil Kegiatan. Kajian Paket Teknologi Mendukung Pelaksanaan IP200 Jagung di Lahan Suboptimal Kab. Gowa. Balai Pengkajian Teknologi Pertanian Sulawesi Selatan.

Anna K.P.Y; J.L. Nenere, Arifin; Solo, S.R; Romuadus, T. S; J.R. Lalopua; B.
Ibrahim dan H. Asmadi, 1985. Tekstur Berlempung. Dasar - Dasar Ilmu Tanah. Badan Kerjasama Perguruan Tinggi Negeri Indonesia Bagian Timur.

Aqil, M. Constance Rapar dan Subachtirodin, 2012. Deskripsi Varietas Unggul Jagung. Edisi Ke Tujuh. ISBN: 979-8940-08-3. Balai Penelitian Tanaman Serealia. Badan Penelitian dan Pengembangan Tanaman Pertanian. Kementerian Pertanian.

Cooke, G.W. 1985. Fertilizing for maximum yield. Granada Publishing Lmt. London. P.75-87. 
Fischer, K.S., and A.F.E. Palmer. 1984. Tropical maize. International Maize and Wheat Improvement Center (CIMMYT).

Franke, G. 1981. Mais (Zea mays L). In Nutzplanzen der Tropen and Subtropen. Band II: 70-92.

Haryono, 2013. Strategi Kebijakan Kementerian Pertanian dalam Optimalisasi Lahan Sub- Optimal Mendukung Ketahanan Pangan Nasional. Prosiding Seminar Nasional Lahan Sub-Optimal "Intensifikasi".

Hanway, J.J. 1971. How a corn plant develops. Iowa State Univ. of Sci. and Tehen. Coop. ext. Services, Ames, Iowa, USA.

Lukitan. B, dan Gofar.N. 2013. Kebijakan Inovasi Teknologi untuk Pengelolaan Lahan Suboptimal Berkelanjutan. Prosiding Seminar Nasional Lahan Suboptimal "Intensifikasi Pengelolaan Lahan Suboptimal dalam Rangka Mendukung Kemanirian Pangan Nasional”. Palembang, 20-21 September. ISBN 979-587-501-9.

Khafidzin, M. 2003. Pengaruh Pemupukan Nitrogen dan Kalium terhadap Hasil dan Kualitas Jagung Semi. Skripsi. Program Studi Hortikultura, Fakultas Pertanian Intitut Pertanian Bogor. Bogor, 40 hal.

Mulyani. A dan Syarwani, 2013. Karakteristik dan Potensi Lahan Sub Optimal untuk Pengembangan Pertanian di Indonesia Prosiding Seminar Nasional Lahan SubOptimal "Intensifikasi Pengelolaan Lahan Sub-Optimal dalam Rangka Mendukung Kemandirian Pangan Nasional, Palembang 20-21 September. ISBN979-587-501-9.

Martilaksono. K dan S. Anwar, 2014. Potensi, Kendala dan Strategi Pemanfaatan Lahan Kering dan Kering Masam untuk Pertanian (Padi, Jagung dan Kedele), Peternakan dan Perkebunan dengan Menggunakan Teknologi Tepat Guna dan Spesifik Lokasi. Departemen Ilmu Tanah dan Sumberdaya Lahan, Fakultas Pertanian IPB.

Muhadjir, F; L. Sibma, and H. van Keulen. 1977. The influence of weather conditions on growth and development of maize crop in the Netherlans Verslag Nr.13 Centrumoor Agrobiologisch Onderzoek, Wageningen, the Netherlands.

Ritchie, S.W, 1989. How a Corn Plant Develops. Special Report No. 48. Ed. J. Clayton Herman. Iowa

Ritchie, S.W. John J. Hanway and Garren O. Benson, 1997. How a Corn Plant Develops Special Report No. 48. Vegetatif Stages and Development. Ed. J. Clayton Herman. Iowa.

Salisbury, F.B., and C.W. Ross, 1978. Plant physiology. Wodsmorth. Publ. Co., Inc., Belmount, California. Dalam Fathan Muhajir, Karakteristik Tanaman Jagung.

Syafruddin, 2015. Keragaan Budidaya jagung pada Lahan Kering di Tingkat Petani dan Perbaikannya di Kabupaten Gowa, Sulawesi Selatan. Prosiding Seminar Nasional, 2015.

Sunarti, 2006. Penentuan Tingkat Masak Benih Jagung. Makalah disampaikan pada Lokakarya Perbenihan Jagung di Balai Penelitian Tanaman Serealia, Maros, 2023 November.

Tollenaar, M. 1977. Sink-source, relationships during reproductive development in maize. A. review, Maydica, XXII, 49-75

Thompson and Troeh, 1975. Soil and Soil Fertility. Nitrogen and Plant Growth, 242-243.

Wereing, P.E. and J.P. Cooper, 1971. Potential crop production. Heinmann Educational Books Ltd, London.

Wahyunto dan Rizatus Shofyati, 2011. Wilayah Potensial Lahan Kering Untuk Mendukung Pemenuhan Kebutuhan Pangan di Indonesia. 